\title{
FMRFamide immunoreactive nervous system in the adult Cassiopeia xamachana scyphopolyp and at the early stages of planuloid formation
}

\author{
V.R. Khabibulina ${ }^{1^{*}}$, V.V. Starunov ${ }^{2}$ \\ ${ }^{I}$ Department of Invertebrate Zoology, Saint Petersburg State University. Universitetskaya nab. 7/ \\ 9, 199034 Saint Petersburg, Russia. E-mail: khabvaleriya@yandex.ru \\ ${ }^{2}$ Zoological institute of the Russian Academy of Sciences, Universitetskaya nab. 1, 199034 Saint \\ Petersburg, Russia.E-mail: starunov@gmail.com
}

ABSTRACT: Studies on the cnidarian nervous system are usually dedicated to model objects such as Hydra and Nematostella vectensis polyps or jellyfish of a few other species, whereas data about other groups and life cycle stages are fragmentary. This study is focused on the nervous system morphology of the mature Cassiopeia xamachana scyphopolyps and during the planuloid formation. We revealed two main groups of the FMRFamideimmunoreactive nerve elements in scyphopolyps. The neurites of the first group accompany musculature in the body column, tentacles and hypostome. Neurites of the second group form a weakly concentrated nerve ring at the margin of the oral disk, which may represent integrative center of the animal. During the planuloid formation no FMRFamide-immunoreactive nerve elements from the mother polyp contribute to the growing bud. This suggests that the FMRFamide-like component of the nervous system in the planuloid develops independently after separation.

How to cite this article: Khabibulina V.R., Starunov V.V. 2020. FMRFamide immunoreactive nervous system in the adult Cassiopeia xamachana scyphopolyp and at the early stages of planuloid formation // Invert. Zool. Vol.17. No.4. P.371-384. doi: 10.15298/ invertzool.17.4.03

KEY WORDS: cnidaria, nervous system, scyphozoa, Cassiopeidae, musculature, budding.

\section{FMRFaмид иммунореактивная нервная система у взрослых полипов Cassiopeia хаmachana и на ранних стадиях образования планулоидов}

\section{В.P. Хабибулина ${ }^{1 *}$, В.В. Старунов²}

\footnotetext{
${ }^{1}$ Кафедра зоологии беспозвоночных, Санкт-Петербургский государственный университет, Университетская набережная 7/9, 199034 Санкт-Петербург, Россия.

E-mail: khabvaleriya@yandex.ru

2 Зоологический институт Российской академии наук, Университетская набережная 1, 199034 Санкт-Петербург, Россия. E-mail: starunov@gmail.com
}

РЕЗЮМЕ: Исследования нервной системы книдарий обычно посвящены медузам или таким модельным объектам как полипы Hydra и Nematostella vectensis, в то время как данные об иных группах или стадиях жизненного цикла фрагментарны. Данная работа фокусируется на морфологии нервной системы взрослых сцифополипов 
Cassiopeia xamachana и ее особенностях при развитии планулоидов. Мы выявили две основных группы FMRFамид-иммунореактивных нервных элементов у сцифополипов. Нейриты первой группы сопровождают мускулатуру в теле, щупальцах и гипостоме. Нейриты второй группы формируют на краю орального диска слабо концентрированное нервное кольцо, которое может представлять собой интегративный центр животного. Во время формирования планулоида FMRFамид-иммунореактивные нервные элементы, участвующие в росте почки, не обнаруживаются. Это может указывать на то, что FMRFамид-подобный компонент нервной системы в планулоиде развивается независимо после отделения.

Как цитировать эту статью: Khabibulina V.R., Starunov V.V. 2020. FMRFamide immunoreactive nervous system in the adult Cassiopeia xamachana scyphopolyp and at the early stages of planuloid formation // Invert. Zool. Vol.17. No.4. P.371-384. doi: 10.15298/ invertzool.17.4.03

КЛЮЧЕВЫЕ СЛОВА: книдарии, нервная система, Scyphozoa, Cassiopeidae, мускулатура, почкование.

\section{Introduction}

Cnidarian nervous systems are the object of the intent attention of the scientific research from the morphology, neurochemistry and neurogenesis studies (Kass-Simon, Pierobon, 2007; Satterlie, 2011; Rentzsch et al., 2017) to more extensive questions of the nervous systems evolution and its origin in Metazoa (Watanabe et al., 2009; Arendt et al., 2016).

Nervous system in Cnidaria is considered to be primitive and includes three elements: the intraepithelially located cnidocytes, sensory cells, and a net of neurons. The neurons can concentrate in plexus-like structures, but never form true ganglia (Satterlie, 2015).Organization of the nervous system differs in two typical cnidarian life forms - the polyp and the medusa (or jellyfish). Jellyfish have multiple conduction systems controlling different types of their behavior, such as swimming, feeding or defense (Mackie, 2004; Satterlie, 2014). These systems integrate in the so-called nerve rings, primitive in Scyphozoa (Satterlie, Eichinger, 2014) and well-developed in Hydrozoa (Koizumi et al., 2015) and Cubozoa (Garm et al., 2007). The nerve rings are formed by the dense circular concentration of neurites at the bell margin.

The nervous system of a polyp, being relatively simple, is studied in more detail, particularly in the model species: the hydrozoan Hydra and the anthozoan Nematostella vectensis. In general polyps possess only one conducting system: the sparse nerve net in the body column and two well-distinguishable concentrations of the nerve elements at the peduncle and at the polyp head (Burnett, Diehl, 1964; Marlow et al., 2009; Gründer, Assman, 2015). The basal concentration is faint, whereas the head concentration is more complex. It includes nerve elements concentration in the mouthparts, at the oral disk, and near the tentacle bases. The latter has the highest concentration and is sometimes treated as a nerve ring. However it is still unclear whether it functions as the integration center and is homologous to the medusa nerve ring (Matsuno, Kageyama, 1984; Koizumi, 2007).

Data on the polyps in other cnidarian taxa are relatively poor, and only several studies are focused on the nervous system. Among Cubozoa only polyps of Tripedalia cystophora were studied in detail using transmission electron microscopy (TEM) (Chapman, 1978). They have a dispersed nerve net in the body and two nerve rings at the oral pole. One of these rings is ectodermal, wherein another one is endodermal, which is unique for cubopolyps.

In Scyphozoa the most studied species is Aurelia aurita (Discomedusae: Semaeostomeae). In scyphopolyps of $A$. aurita the nervous system was described using TEM (Chia et al., 1984) and FMRFamide labeling (Sakaguchi et al., 1999). The concentration of nerve elements 


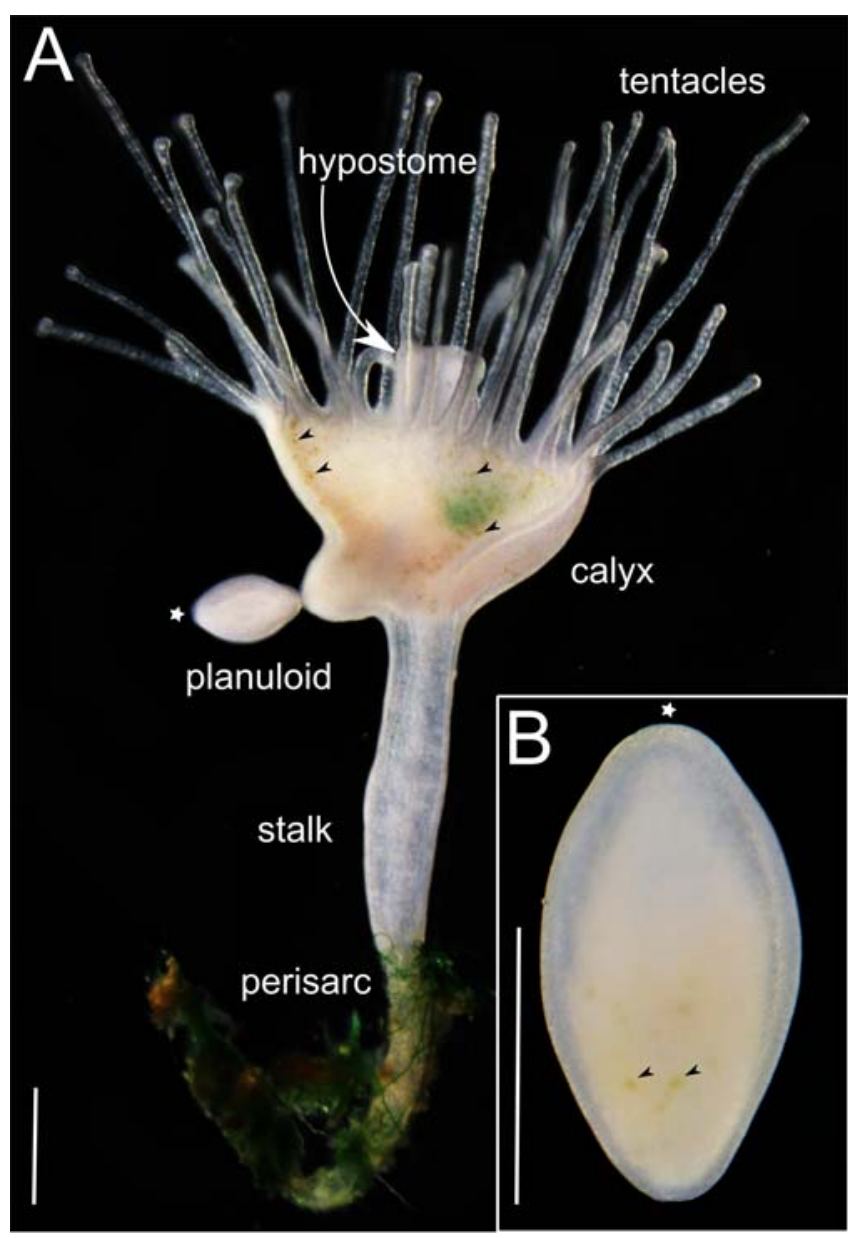

Fig. 1. Polyp and planuloid of Cassiopeia xamachana, alive specimens. A - polyp of C. xamachana with developing planuloid. B - newly separated planuloid of C. xamachana. The anterior end of the planuloid is marked with asterisk, black arrowheads label the photosymbyonts.

Scale bar: A $-1 \mathrm{~mm}$; B $-0.5 \mathrm{~mm}$.

Рис. 1. Полип и планулоид Cassiopeia xamachana, прижизненные фотографии. А - полип $C$. xamachana с развивающимся планулоидом, В - недавно отделившийся планулоид C. xamachana. Передний конец планулоида обозначен звездочкой, черные наконечники стрелок указывают на фотосимбионтов.

Масштаб: А -1 мм; В $-0,5$ мм.

is lower than in other cnidarian groups. Neurites are most numerous at the oral disk, however they never form a dense nerve ring. There are also four groups of FMRFamide-immunoreactive neurons, accompanying four longitudinal septal muscle bands (Sakaguchi et al., 1999).

Data on the scyphopolyps morphology in the order Rhizostomeae is limited to the description of the external anatomy of the polyps and special features of their asexual propaga- tion (Schiariti et al., 2008; Kienberger et al., 2018). Recently we have studied the musculature of the Cassiopeia polyps (Khabibulina, Starunov, 2019). Further study on the nervous system organization in this species is important not only for the comparative analysis, but also because polyps of Cassiopeidae family have the special type of budding (Arai, 1997). Instead of the lateral budding, typical for other scyphozoans, in which new polyps develop directly on the 
mother organism (Adler, Jarms, 2009), they produce ciliary stages - planuloids, which look similar to the typical planula larva (Fig. 1A, B). After a short period of swimming they settle down and transform into the new polyps. The development and metamorphosis of the Cassiopeidae planuloids were studied previously histologically (Bigelow, 1900) and with scanning electron microscopy (Van Lieshout, Martin, 1992). Presence of the solitary neurons in planuloids was also shown at the ultrastructural level (Hofmann, Honegger, 1990), but their origin and topology remain unknown.

This study is aimed to describe the nervous system features of the C. xamachana Bigelow, 1982 scyphopolyps and at the early stages of the planuloid development using immunolabeling against FMRFamide neuropeptide. We revealed two morphologically distinct groups in FMRFamide immunoreactive nervous system of the scyphopolyp. We also found, that these nerve elements were not involved in the planuloid formation.

\section{Material and methods}

The culture of the Cassiopeia xamachana Bigelow, 1982 was kept in artificial sea water with a salinity of about $32-35 \%$ at room temperature. Scyphopolyps were maintained in plastic tanks $(25 \times 15 \times 8 \mathrm{~cm})$ and were fed with the Artemia nauplii every two-three days, depending on the digestion time.

Specimens were anesthetized in $7.5 \%$ $\mathrm{MgCl}_{2} * 6 \mathrm{H}_{2} \mathrm{O}$ and then fixed in $4 \%$ paraformaldehyde in $0,1 \mathrm{M}$ phosphate-buffered saline (PBS) at room temperature for 1-2 hours. After fixa- tion, the specimens were washed in Phosphatebuffered saline $+1.5 \%$ Triton-X100 (PBT) for 30 minutes and then 3 times for 15 minutes. After washing the specimens were incubated in $4 \mathrm{M}$ glycine in PBS for 1 hour and then washed again in PBT 2 times for 15 minutes. Next, the specimens were preincubated in $1.5 \%$ bovine serum albumin (BSA) in PBS for $1-1.5$ hours and washed again in PBS 2 times for 15 minutes. All incubations and washing steps were made at the room temperature.

The preincubated specimens were incubated with the primary antibodiy to FMRFamide (20091, Immunostar, diluted 1:1000 in PBS) for 2 days at $4{ }^{\circ} \mathrm{C}$. After the incubation polyps were washed in PBS 3 times for 30 minutes and then incubated with the secondary antibodies Alexa Fluor 488 goat anti rabbit (A-11034, Invitrogen) or CF633 donkey anti rabbit (SAB4600132, Sigma) diluted 1:800 - 1:1000, and with TRITC-conjugated phalloidin (Sigma, P1951; dilution 1:100) in PBT for 2 days at $4{ }^{\circ} \mathrm{C}$. After the last incubation specimens were carefully washed in PBS at room temperature and mounted in Mowiol 4-88 (Wurm et al, 2010). The confocal stacks were acquired using Leica TCS SP5 Laser Scanning Confocal Microscope, and analyzed using Fiji (Schindelin et al, 2012) and Adobe Photoshop. The schemes were done with Inkscape 0.92 software.

\section{Results}

In the scyphopolyps of Cassiopeia xamachana elements labeled by FMRFamide antibody were situated irregularly and formed specific location patterns. The specific immunoreac-

Fig. 2. Polyps of Cassiopeia xamachana labeled with FMRFamide antibody (cyan) and TRITC-conjugated phalloidin (red). A - the stalk of polyp, B-C - the sectors of polyp calyx with septal muscles, D - the stalk to calyx transition of polyp, dotted line demarcates the place of septal muscle, E-F — the sectors of the polyp calyx with solitary neurites. FMRFamide-like immunoreactive elements are pointed with arrowheads.

Abbreviations: sm — septal muscle bands, sn — septal neurites, sb — photosymbyonts cells. Scale bar: $100 \mu \mathrm{m}$.

Рис. 2. Полипы Cassiopeia xamachana меченные антителами к FMRFaмиду (голубой) и TRITCконъюгированному фаллоидину (красный). A - стебелек полипа, B-C - участок чашечки полипа с септальными мышцами, D — переход между стебельком и чашечкой полипа, пунктирная линия обозначает место положения септальной мышцы, E-F - участки чашечки полипа с одиночными нейритами. FMRF-амид-подобные иммунореактивные элементы указаны наконечниками стрелок. Обозначения: sm - ленты септальных мышц, sn - септальные нейриты, sb - клетки фотосимбионтов. Масштаб 100 мкм. 


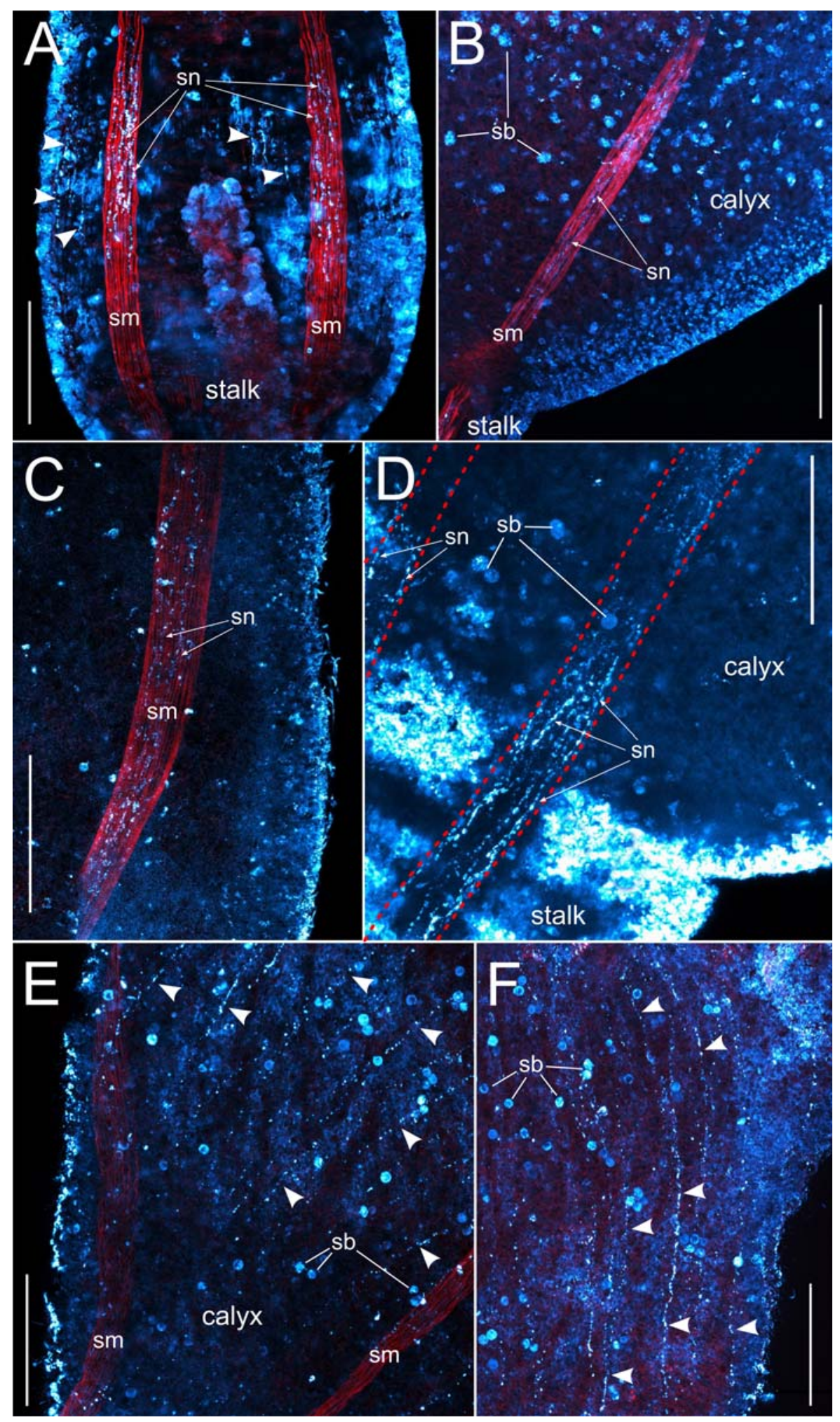




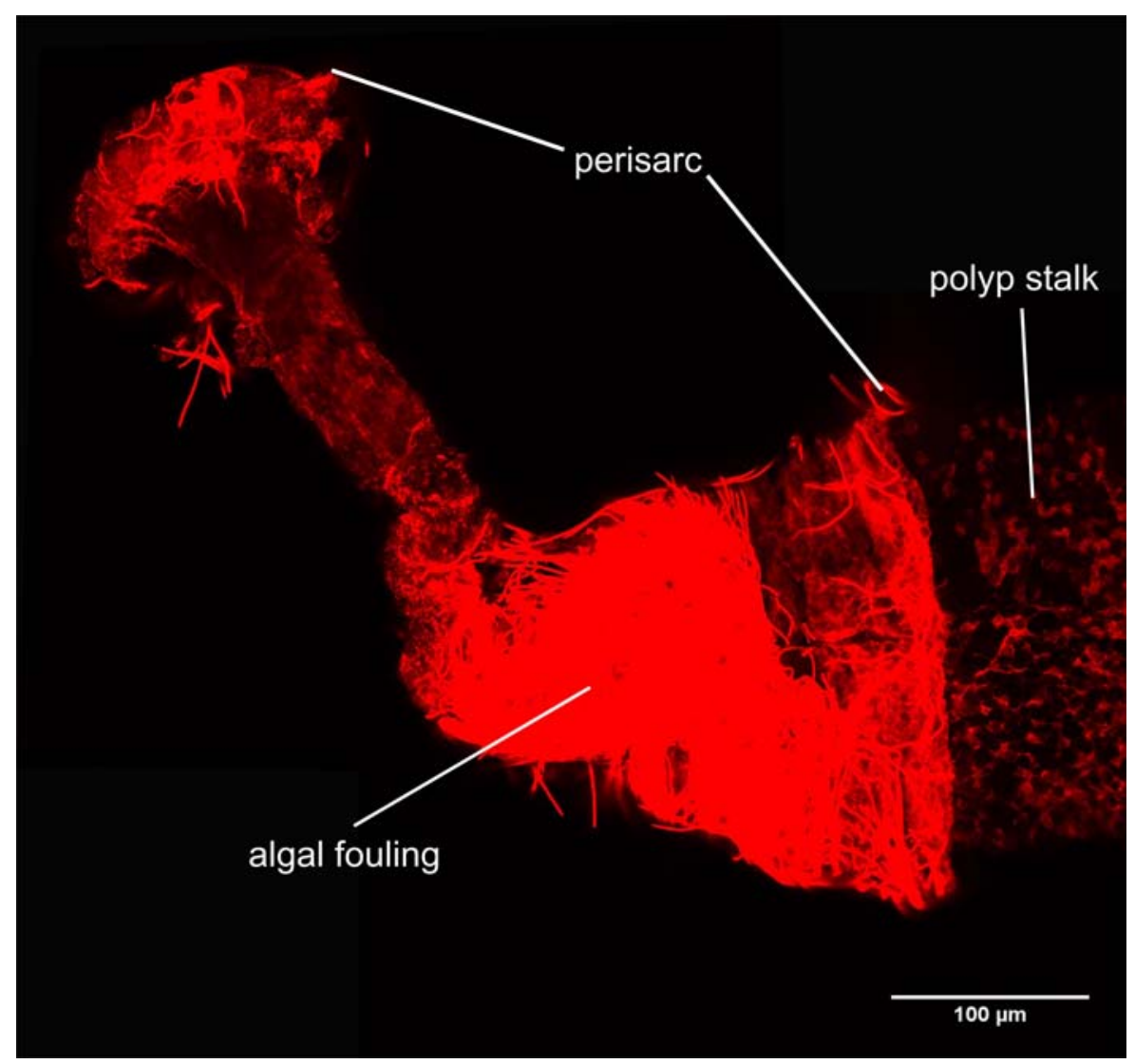

Fig. 3. Perisarc and the base of stalk of the Cassiopeia xamachana polyp. Visible structures are visualized due to autofluorescence under $633 \mathrm{~nm}$ laser of chlorophyll in fouling algae and chitin component in perisarc. Рис. 3. Перисарк и основание стебелька полипа Cassiopeia xamachana. Видимые структуры визуализированы благодаря автофлуоресценции хлорофилла водорослей-обрастателей и хитинового компонента перисарка в свете 633-нм лазера.

tive reaction was detected only in cell processes, and not in perikarya. We also noticed a high level of background labeling. This is possibly caused by non-specific binding of antibodies with the numerous secretory cells and surface mucus.

In the polyp stalk FMRFamide-like immunoreactive elements are found predominantly alongside the four septal muscular bands. Every muscle band in the stalk is accompanied by 5 6 fibers with large vesicles. They run in close proximity with muscle fibers throughout the stalk length (Fig. 2A) and then in the calyx (Fig. 2B-D). At the place of stalk-calyx transition the septal neurites become thinner and their amount decreases, the vesicles inside them become smaller (Fig. 2D). Apart from the septal FMRFamide-like immunoreactive elements, thin longitudinal neurites are also observed in the polyp body. These neurites run from the stalk (Fig. 2A), then disperse in the calyx to the oral disk (Fig. 2E-F) without branching or rapprochement. In the polyp peduncle the immunoreactive elements are impossible to trace because of the dense perisarc covering and autofluorescence of the microalgae fouling (Fig. 3).

At the oral disk near the basements of the tentacles FMRFamide-like immunoreactive elements form a circumhypostomal ring-shaped cluster - a nerve ring (Fig. 4A-C). The concentration of fibers in this circular cluster is the highest 

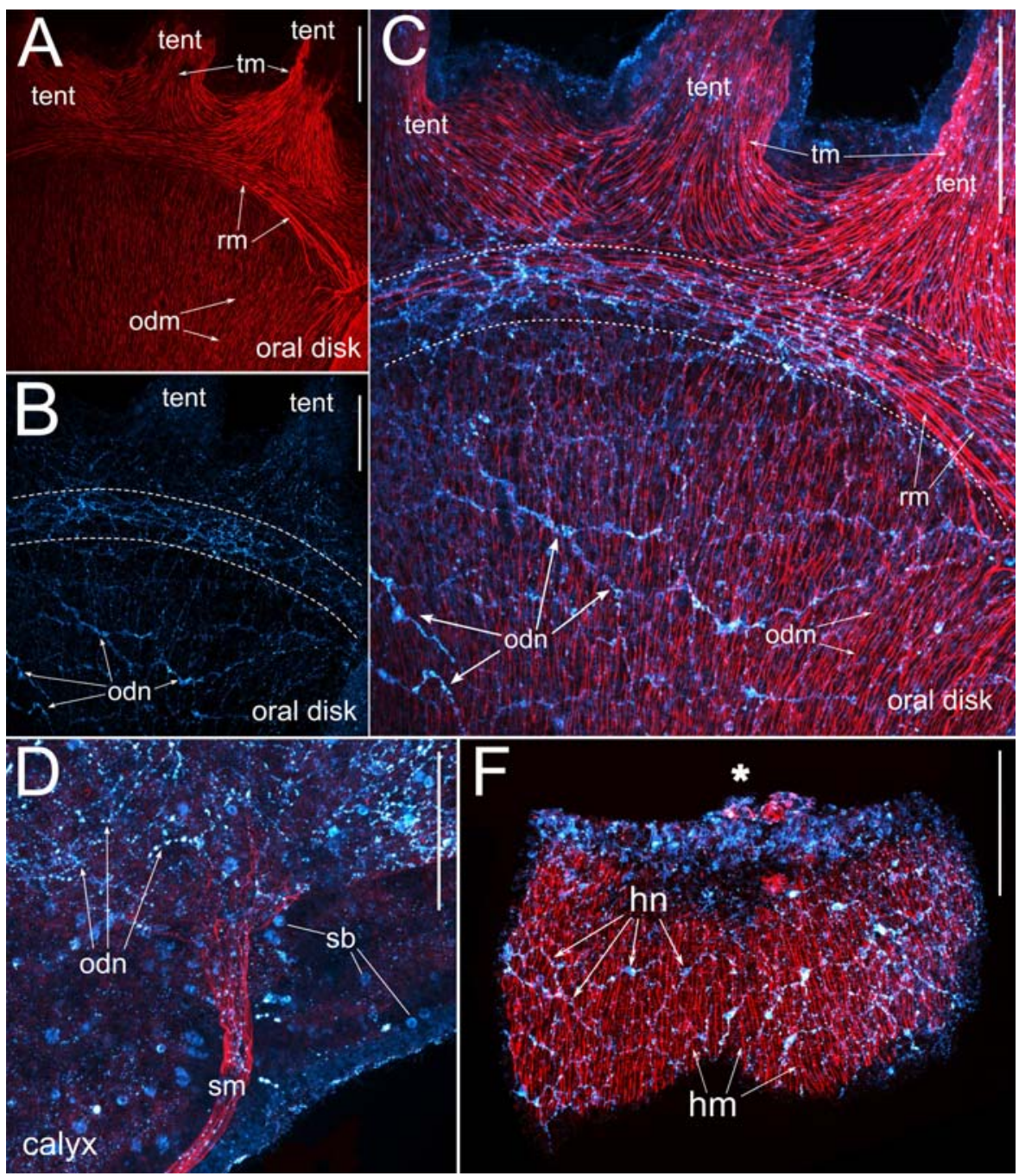

Fig. 4. The parts of oral disk and hypostome of the Cassiopeia xamachana polyp labeled with FMRFamide antibody (cyan) and TRITC-conjugated phalloidin (red). A - musculature of the oral disk and the tentacle bases, view from above, B - FMRFamide-like immunoreactive elements of the oral disk and the tentacle bases, view from above, $\mathrm{C}$ - combined image of the musculature and FMRFamide-like immunoreactive elements of the oral disk, D - the calyx sector near the oral disk, F - hypostome, the place of mouth opening is marked with asterisk. The border of the nerve ring is demarcated by dotted line.

Abbreviations: $\mathrm{hm}$ - hypostomal muscles, $\mathrm{hn}$ — hypostomal neurites, odm — oral disk muscles, odn — oral disk neurites, $\mathrm{rm}$ - ring muscle, $\mathrm{sb}$ - photosymbyonts cells, $\mathrm{sm}$ - septal muscle, tent — tentacles, $\mathrm{tm}$ - tentacle muscles. Scale bar: $100 \mu \mathrm{m}$.

Рис. 4. Участки орального диска и гипостома полипов Cassiopeia xamachana меченные антителами к FMRFамиду (голубой) и TRITC-конъюгированному фаллоидину (красный). A - мускулатура орального диска и оснований щупалец, вид сверху, В - FMRFамид-подобные иммунореактивные элементы орального диска и оснований щупалец, вид сверху, С - совмещенное изображение FMRFамид-подобных иммунореактивных элементов и мускулатуры орального диска, D - участок чашечки вблизи от орального диска, $\mathrm{F}$ - гипостом, место расположения ротового отверстия обозначено звездочкой. Граница нервного кольца обозначена пунктирной линией.

Обозначения: $\mathrm{hm}$ - мышцы гипостома, $\mathrm{hn}$ - нейриты гипостома, odm - мышцы орального диска, odn нейриты орального диска, $\mathrm{rm}$ - кольцевая мускулатура, $\mathrm{sb}$ - клетки фотосимбионтов, $\mathrm{sm}$ - септальная мускулатура, tent — щупальца, tm - мышцы щупалец. Масштаб 100 мкм. 

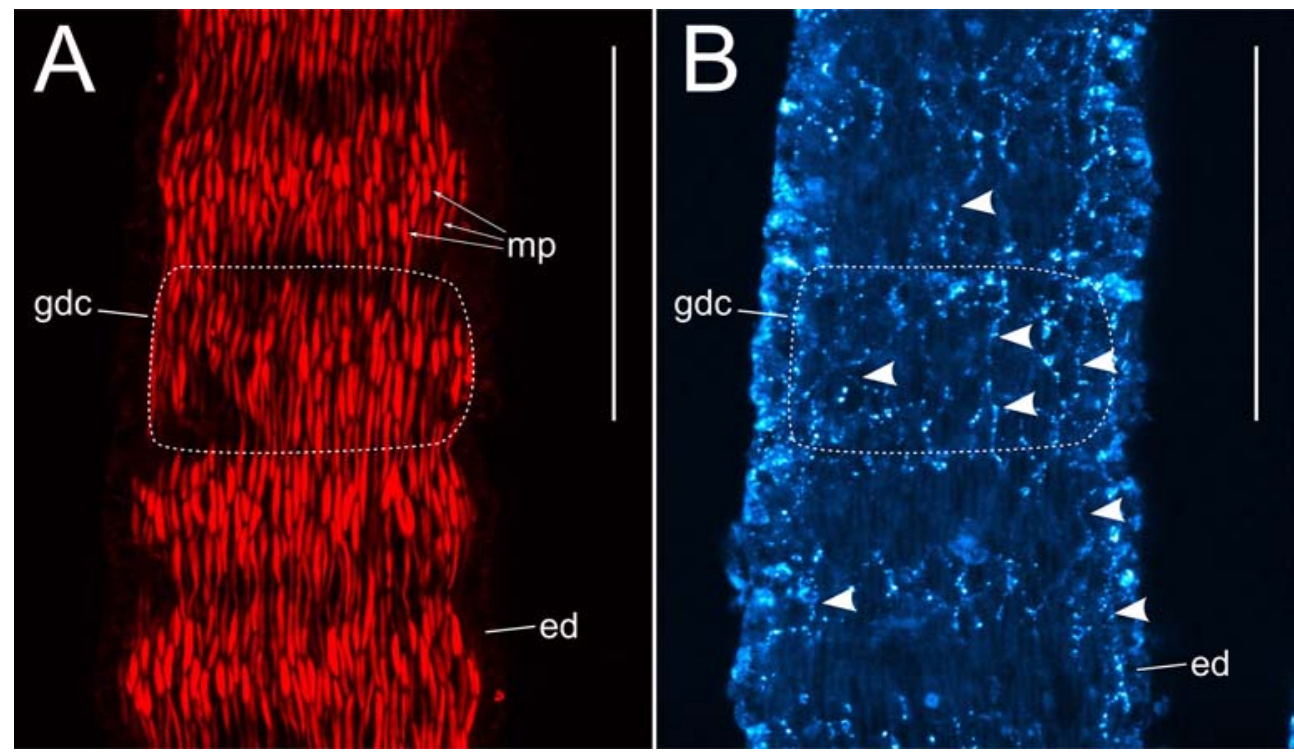

Fig. 5. The middle part of the Cassiopeia xamachana polyp tentacle. A - muscle processes of tentacle labeled with TRITC-conjugated phalloidin, B - neurites in tentacle labeled with FMRFamide antibody. Single FMRFamide-like immunoreactive elements are pointed with arrowheads.

Abbreviations: ed - the layer of tentacle epidermal cells, gdc — columnar gastrodermal cell of the tentacle, dotted line demarcates the cell border, $\mathrm{mp}$ - muscle processes. Scale bar: $50 \mu \mathrm{m}$.

Рис. 5. Средняя часть щупальца полипа Cassiopeia xamachana. А - мышечные отростки щупальца меченные TRITC-конъюгированным фаллоидином, В — нейриты в щупальце меченные антителами к FMRFамиду. Отдельные FMRFамид-подобные иммунореактивные элементы указаны наконечниками стрелок.

Обозначения: ed - слой эпидермальных клеток щупальца, gdc - столбчатая гастродермальная клетка щупальца, пунктирная линия обозначает границу клетки, $\mathrm{mp}$ - мышечные отростки. Масштаб 50 мкм.

in the body. The net over the ring muscle (Fig. 4B) is so dense that individual cells are not distinguishable (Fig. 4A). On the side view of the polyp calyx, the border of the nerve ring coincides with the septal muscle endings (Fig. 4D). From the nerve ring separate fibers branch out and enter the tentacles. At the oral disk inward from the nerve ring FMRFamide-like immunoreactive elements with large vesicles form the loose net. The similar FMRFamide-like elements are observed in the hypostome (Fig. 4F) however the amount of the fibers here is lower than in the oral disk. In both oral disk and hypostome, there is no correspondence between the direction of the FMRFamidelike immunoreactive and muscular fibers.

In tentacles FMRFamide-like immunoreactive elements form the diffuse meshwork (Fig. 5). They do not strictly follow the direction of the muscle processes.
During the planuloid development no FMRFamide-like immunoreactivity was found in the growing bud evagination. The septal and solitary longitudinal immunoreactive elements are well-observed close to the site of the planuloid growth in the calyx (Fig. 6A). They never change their typical direction and do not form processes to the growing planuloid, accompanying the branching septal muscle fibers.

In the newly separated planuloid the FMRFamide-like immunoreactivity is very weak. No immunoreactive elements were observed at the posterior end that previously was connected to the mother polyp. In the middle part only a few thin longitudinal fibers are distinguishable (Fig. $6 \mathrm{~B}$ ), and their location does not strictly correspond with the muscle fibers topology. At the distal end of the planuloid there is a disperse group of the FMRFamide-immunoreactive elon- 

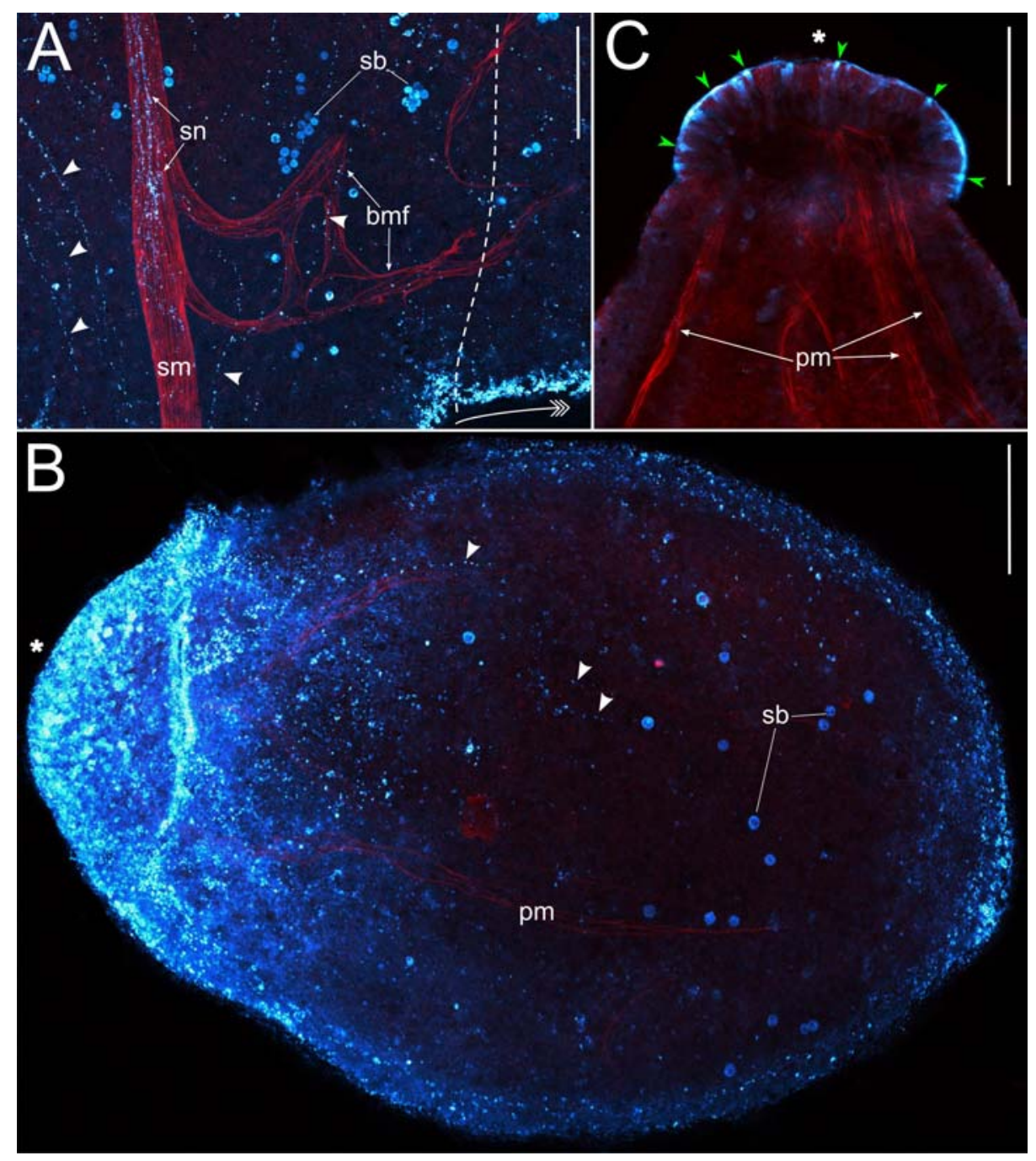

Fig. 6. Forming and separated planuloids of Cassiopeia xamachana labeled with FMRFamide antibody (cyan) and TRITC-conjugated phalloidin (red). A - the base of growing planuloid protrusion near the septal muscle band of polyp, the approximate border between calyx and protrusion is marked with the intermittent line, B - separated planuloid, C - the anterior end of the planuloid, green arrowheads point the possible sensory cells. The anterior end of the planuloid marked with asterisk, the direction of planuloid growth is shown with arrow, single FMRFamide-like immunoreactive elements are pointed with white arrow heads. Abbreviations: bmf — branched off septal muscle fibers entering the growing planuloid, $\mathrm{pm}$ - planuloid muscles, $\mathrm{sb}-$ photosymbyonts cells, sm - septal muscle band, sn - septal neurites. Scale bar: A $-100 \mu \mathrm{m} ; \mathrm{B}, \mathrm{C}-50 \mu \mathrm{m}$.

Рис. 6. Формирующийся и отделившийся планулоиды Cassiopeia xamachana меченные антителами к FMRFамиду (голубой) и TRITC-конъюгированному фаллоидину (красный). А - основание выпячивания растущего планулоида вблизи септальной мышечной ленты полипа, приблизительная граница между чашечкой и основанием выпячивания показана прерывистой линией, В - отделившийся планулоид, C - передний конец планулоида, зеленые наконечники стрелок указывают на вероятные сенсорные клетки. Передний конец планулоида обозначен звездочкой, направление роста планулоида показано стрелкой, отдельные FMRF-амид-подобные иммунореактивные элементы указаны наконечниками стрелок.

Обозначения: bmf - ответвившиеся от септальной мышцы волокна, проникающие в растущий планулоид, $\mathrm{pm}$ мышцы планулоида, sb - клетки фотосимбионтов, sm - септальная мышечная лента, sn - септальные нейриты. Масштаб: А - 100 мкм; В, С - 50 мкм. 


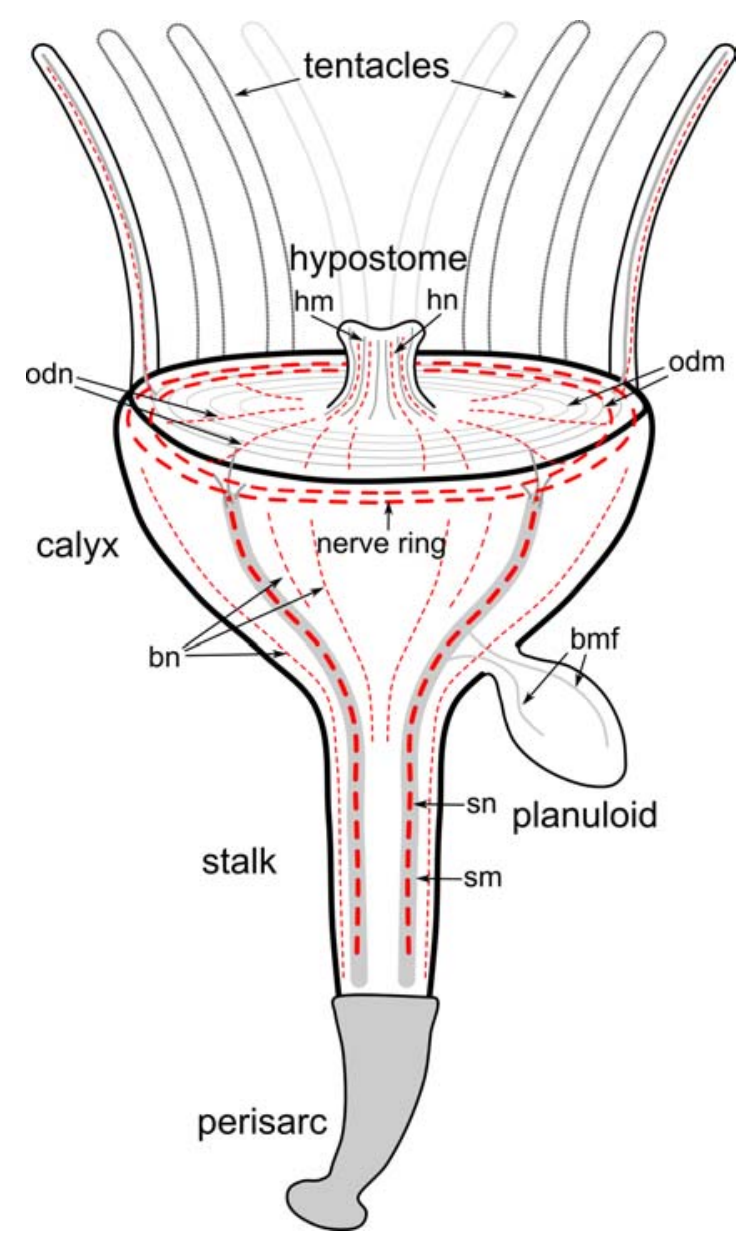

Fig. 7. Scheme of the muscular and nervous system of the Cassiopeia xamachana polyp with growing planuloid. Muscle elements are shown in grey lines, nervous system elements are shown in red intermittent lines.

Abbreviations: bmf — branched off septal muscle fibers entering the growing planuloid, bn — body solitary neurites, $\mathrm{hm}$ — hypostomal muscles, hn — hypostomal neurites, odm — oral disk muscles, odn — oral disk neurites, sm — septal muscle band, sn - septal nerites.

Рис.7. Схема мышечной и нервной системы полипа Cassiopeia xamachana с растущим планулоидом. Мышечные элементы показаны серыми линиями, элементы нервной системы показаны прерывистыми красными линиями.

Обозначения: $\mathrm{bmf}$ - ответвившиеся от септальной мышщы волокна, проникающие в растущий планулоид, bn одиночные нейриты тела, hm - мышцы гипостома, $\mathrm{hn}$ - нейриты гипостома, odm - мышцы орального диска, odn - нейриты орального диска, sm - септальная мышечная лента, sn - септальные нейриты.

gated cells, located in the knot-like area (Fig. 6C). Despite the strong fluorescent signal, we never observed any processes of these cells.

In all specimens the photosymbyonts Symbiodinium sp. typical for Cassiopeidae, were found. The cells were detected due to autofluorescence of algal chlorophyll in the same wavelength band as the dye of the secondary antibodies.

\section{Discussion}

The scyphopolyps of Cassiopeia xamachana have two groups of FMRFamide-immunoreactive nerve elements (Fig. 7). The first group is the neurites accompanying muscle elements in the different body parts. The second group includes circular neurites, concentrated in the nerve ring. 
The first and most conspicuous part of the body FMRFamide-like nerve elements are neurites accompanying the four septal muscle bands. Their location apparently suggests the involvement of the FMRFamide-like nerve elements in muscle activity control. This assumption may be supported by the data on another cnidarian species Hydractinia echinata, in which FMRFamide-immunoreactive neurons provide neuromodulation of the motor signal in smooth muscles (Plickert, Schneider, 2004). The involvement of the FMRFamide-immunoreactive neuronal elements in the control of the swimming muscle activity was also shown for scyphozoan jellyfish (Satterlie, Eichinger, 2014).

The second part of the body FMRFamidelike nerve elements was found in the tentacles. These neurites form diffuse net of short branched processes without any sign of concentration. Probably in this case FMRFamide-immunoreactive elements are also involved in neuromuscular interactions, transmitting the signal directly from the sensory cells in epidermis to the short tentacle muscle fibers (Walker et al., 2009).

The third part of the body FMRFamide-like nerve elements is located in the hypostome and the surrounding region of the oral disk. In this group the neurons also form a diffuse network, but they have thicker processes than in the tentacles, and are more numerous. These neurons possibly regulate the complex movements of the hypostome.

The second group of the FMRFamide-immunoreactive nerve elements is located at the margin of the oral disk, near the tentacles bases, where circumhypostomal nerve elements form the nerve ring. Circular nerve structures at the oral pole are found in polyp stages of the other cnidarian groups (Watanabe et al., 2009). Similar nerve concentrations are considered as the nerve ring in Hydra (Koizumi, 2007; Hufnagel, Kass-Simon, 2016), in Nematostella vectensis (Marlow et al., 2009), and in Tripedalia cystophora (Chapman, 1978). In all these cases neurites in the nerve ring are located densely and almost form nerve cords. On the contrary, in the scyphopolyps - as it was shown for Aurelia aurita (Sakaguchi et al., 1999) and in this study for Cassiopeia xamachana - the density of neuron processes is relatively low and they never form a concentrated cord. However, this cluster is the most condensed part of the nervous system in the whole polyp body. In addition, the neurites of septal, tentacle and hypostomal musculature are probably interconnected with the nerve ring. Thus, we can suppose that in scyphopolyps the nerve ring cluster may function as an integrative center of the polyp the same way as in other cnidarians.

In general, the FMRFamide-positive system organization in the scyphopolyps is similar to that in the Anthozoa. Part of the FMRFamidelike neurites forms well-distinguishable longitudinal patterns in the body column and colocalizes with musculature. The anthozoans and scyphozoans share some similar morphological features of muscle system. Muscle elements are organized in functional groups: septal muscle bands in the scyphopolyps (Chia et al., 1984; Khabibulina, Starunov, 2019) or mesenterial columnar muscles in the anthopolyps (Jahnel et al., 2014). In both cases FMRFamide-like neurons accompany these muscle groups (Marlow et al., 2009; this study). At the same time similar neuronal structures were not found in the Hydrozoa and the Cubozoa. Muscle fibers in these polyps are more evenly dispersed in the body column (Mueller, 1950; Chapman, 1978; Leclère, Röttinger, 2017). Similarly, body FMRFamide-like neurites in Hydrozoa or Cubozoa are never organized in dense groups, but form a diffuse net with the prevalence of the longitudinally oriented nerve processes (Kass-Simon, Pierobon, 2007, Mayorova, Kosevich, 2013).

FMRFamide labeling was also shown in the sensory cells of the jellyfish rhopalia (Scogh et al., 2006; Nakanishi et al., 2009). Sensory function was also suggested for FMRFamide neurons found in the ectodermal layer of the mature planula larva (Martin, 1992; Nakanishi et al, 2008). Interestingly, the sensory cells are replaced by motor neurons during planula to polyp metamorphosis and no FMRFamide-positive cells of sensory type were described in the polyps to date (Martin, 2000; Mayorova, Kosevich, 2013; Pennati et al., 2013). We also did 
not find sensory FMRFamide-like cells in $C$. xamachana polyps. Nevertheless, we found the region of the FMRF-positive cells at the anterior end of the planuloid. The shape of these cells and their location remind of the FMRFamidelike sensory cells in the planulae. However, it is difficult to determine the exact cell specification because of the strong non-specific labeling in this region.

Except for the FMRFamide-immunoreactive cells at the anterior end the number of FMRFamide-positive nerve elements in the planuloid is extremely low. During its formation, the nearest septal muscle noticeably reorganizes: several muscle fibers branch off the muscle band and enter the tissue protrusion of the developing planuloid. Nevertheless, we did not observe any change in the number or location of the FMRFamide-positive neurites near the site of the planuloid growth. After the separation, only a few very faint longitudinal nerve fibers were revealed in the middle part of planuloid, which is consistent with the ultrastructural data (Hofmann, Honegger, 1990). Although the direction of these solitary neurites coincides with that of developing muscle fibers, the neurites do not localize in the close proximity to the forming muscle bands and may not provide a neuromotor function.

We can suggest that FMRFamide-positive neurons of the mother polyp are not involved in the planuloid growth. During the free-swimming period FMRFamidergic nervous system barely starts to form. The putative sensory cells at the anterior end of the planuloid are probably persisting until the moment of attachment, similarly to the planula larvae (Martina, 2000). The locomotion of the planuloid is ciliary, growing muscles only provide slight body shape changes. However, by the moment of settlement the musculature of planuloid resembles that of the polyp. Probably at this moment the active differentiation of the neurons controlling the muscular system takes place. In this way a new polyp may relatively quickly proceed to the complex feeding and stress behavior.

Thereby the FMRFamide-positive nervous system in scyphopolyps of Cassiopeia xam- achana is made up of two parts. The first part is directly connected with the active muscular elements such as septal, tentacle and hypostomal muscles, providing motor function, and also includes solitary longitudinal elements in the stalk and calyx. The second one is a relatively loose nerve ring - the integration center of the polyp, located at the oral disk.

\section{Acknowlegments}

The scientific research was performed at the Centre "Chromas" and "Centre for Culture Collection of Microorganisms" of Research Park of St. Petersburg State University as well as the Core Facilities Centre "Taxon" of the Zoological Institute Russian Academy of Sciences (St Petersburg, Russia). The work was supported by the Zoological Institute of the Russian Federation(NIOKTR: AAAA-A19-1190206900767). The authors have declared that no competing interests exist.

\section{Compliance with ethical standards}

Conflict of Interest: The authors declare that they have no conflict of interest.

Ethical approval: This article does not contain any studies with animals performed by any of the authors.

\section{References}

Adler L., Jarms G. 2009. New insights into reproductive traits of scyphozoans: special methods of propagation in Sanderia malayensis GOETTE, 1886 (Pelagiidae, Semaeostomeae) enable establishing a new classification of asexual reproduction in the class Scyphozoa // Mar. Biol. Vol.156. No.7. P.1411-1420.

Arai M.N. 1997. A functional biology of Scyphozoa. Springer Science \& Business Media. 316 p.

Arendt D., Tosches M.A., Marlow H. 2016. From nerve net to nerve ring, nerve cord and brain - evolution of the nervous system // Nat. Rev. Neurosci. Vol.17. No.1. P.61.

Bigelow R.P. 1892. On a new species of Cassiopea from Jamaica // Zool. Anz. Vol.15. P.212-214.

Bigelow R.P. 1900. The anatomy and development of Cassiopea xamachana // Boston Society of Natural History. Memoirs. Vol.5. No.6. P.191-236, plates 31-38.

Burnett A.L., Diehl N.A. 1964. The nervous system of Hydra. I. Types, distribution and origin of nerve elements // J. Exp. Zool. Vol.157. No.2. P.217-226. 
Chapman D.M. 1978. Microanatomy of the cubopolyp, Tripedalia cystophora (Class Cubozoa) // Helgolaender wissenschaftliche meeresuntersuchungen. Vol.31. No.1. P.128.

Chia F.S., Amerongen H.M., Peteya D.J. 1984. Ultrastructure of the neuromuscular system of the polyp of Aurelia aurita L., 1758 (Cnidaria, Scyphozoa) // J. Morphol. Vol.180. No.1. P.69-79.

Garm A., Poussart Y., Parkefelt L., Ekström P., Nilsson D.E. 2007. The ring nerve of the box jellyfish Tripedalia cystophora // Cell Tissue Res. Vol.329. No.1. P.147-157.

Gründer S., Assmann M. 2015. Peptide-gated ion channels and the simple nervous system of Hydra // J. Exp. Zool. Vol.218. No.4. P.551-561.

Hofmann D.K., Honegger T.G. 1990. Bud formation and metamorphosis in Cassiopea andromeda (Cnidaria: Scyphozoa): A developmental and ultrastructural study // Mar. Biol. Vol.105. No.3. P.509-518.

Hufnagel L.A., Kass-Simon G. 2016. The two nerve rings of the hypostomal nervous system of Hydra vulgaris - an immunohistochemical analysis // Cell Tissue Res. Vol.366. No.2. P.255-269.

Jahnel S.M., Walzl M., Technau U. 2014. Development and epithelial organization of muscle cells in the sea anemone Nematostella vectensis // Front. Zool. Vol.11. No.1. P.44.

Kass-Simon G., Pierobon P. 2007. Cnidarian chemical neurotransmission, an updated overview// Comp. Biochem. Phys. A. Vol.146. No.1. P.9-5.

Khabibulina V., Starunov V. 2019. Musculature development in planuloids of Cassiopeia xamachana (Cnidaria: Scyphozoa) // Zoomorphology. Vol.138. No.3. P.297-306.

Kienberger K., Riera-Buch M., Schönemann A.M., Bartsch V., Halbauer R., Prieto L. 2018. First description of the life cycle of the jellyfish Rhizostoma luteum (Scyphozoa: Rhizostomeae)// PloS one. Vol.13. No.8.

Koizumi O. 2007. Nerve ring of the hypostome in hydra: is it an origin of the central nervous system of bilaterian animals? // Brain Behav. Evol. Vol.69. No.2. P.151-159.

Koizumi O., Hamada S., Minobe S., Hamaguchi-Hamada K., Kurumata-Shigeto M., Nakamura M., Namikawa H. 2015. The nerve ring in cnidarians: its presence and structure in hydrozoan medusae // Zoology. Vol.118. No.2. P.79-88.

Leclère L., Röttinger E. 2017. Diversity of cnidarian muscles: function, anatomy, development and regeneration // Front. Cell Dev. Biol. Vol.4. P.157.

Mackie G.O. 2004. Central neural circuitry in the jellyfish Aglantha // Neurosignals. Vol.13. No.1-2. P.5-19.

Marlow H.Q., Srivastava M., Matus D.Q., Rokhsar D., Martindale M.Q. 2009. Anatomy and development of the nervous system of Nematostella vectensis, an anthozoan cnidarian // Dev. Neurobiol. Vol.69. No.4. P.235-254.

Martin V.J. 1992. Characterization of a RFamide-positive subset of ganglionic cells in the hydrozoan planular nerve net // Cell Tissue Res. Vol.269. No.3. P.431-438.
Martin V.J. 2000. Reorganization of the nervous system during metamorphosis of a hydrozoan planula // Inv. Biol. Vol.119. No.3. P.243-253.

Matsuno T., Kageyama T. 1984. The nervous system in the hypostome of Pelmatohydra robusta: the presence of a circumhypostomal nerve ring in the epidermis // J. Morphology. Vol.182. No.2. P.153-168.

Mayorova T., Kosevich I. 2013. FMRFamide immunoreactivity pattern in the planula and colony of the hydroid Gonothyraea loveni // Zoology. Vol.116. No.1. P.9-19.

Mueller J.F. 1950. Some observations on the structure of hydra, with particular reference to the muscular system // Trans. Am. Microsc. Soc. Vol.69. No.2. P.133147.

Nakanishi N., Hartenstein V., Jacobs D. K. 2009. Development of the rhopalial nervous system in Aurelia sp. 1 (Cnidaria, Scyphozoa) // Dev. Genes Evol. Vol.219. No.6. P.301-317.

Nakanishi N., Yuan D., Jacobs D.K., Hartenstein V. 2008. Early development, pattern, and reorganization of the planula nervous system in Aurelia (Cnidaria, Scyphozoa) // Dev. Genes Evol. Vol.218. No.10. P.511-524.

Pennat R., Dell'Anna A., Pagliara P., Scarì G., Piraino S., De Bernardi F. 2013. Neural system reorganization during metamorphosis in the planula larva of Clava multicornis (Hydrozoa, Cnidaria) // Zoomorphology. Vol.132. No.3. P.227-237.

Plickert G., Schneider B. 2004. Neuropeptides and photic behavior in Cnidaria // Hydrobiologia. Vol.530. No.13. P.49-57.

Rentzsch F., Layden M., Manuel M. 2017. The cellular and molecular basis of cnidarian neurogenesis // Wiley Interdiscip. Rev. Dev. Biol. Vol.6. No.1. e257.

Sakaguchi M., Imai Y., Nomoto S. 1999. The presence and distribution of RFamide-like immunoreactive nerve fibers in scyphistomae of Aurelia aurita // Comp. Biochem. Physiol. Part A Mol. Integr. Physiol. Vol.122. No.2. P.261-266.

Satterlie R.A. 2011. Do jellyfish have central nervous systems? // J. Exp. Zool. Vol.214. No.8. P.1215-1223.

Satterlie R.A. 2014. Multiple conducting systems in the cubomedusa Carybdea marsupialis // Biol. Bull. Vol.227. No.3. P.274-284.

Satterlie R.A. 2015. Cnidarian nerve nets and neuromuscular efficiency // Integr. Comp. Biol. Vol.55. No.6. P.1050-1057.

Satterlie R.A., Eichinger J. M. 2014. Organization of the ectodermal nervous structures in jellyfish: scyphomedusae // Biol. Bull. Vol.226. No.1. P.29-40.

Schiariti A., Kawahara M., Uye S., Mianzan H. W. 2008. Life cycle of the jellyfish Lychnorhiza lucerna (Scyphozoa: Rhizostomeae) // Mar. Biol. Vol.156. No.1. P.1-12.

Schindelin J., Arganda-Carreras I., Frise E., Kaynig V., Longair M., Pietzsch, et al. 2012. Fiji: an open-source platform for biological-image analysis // Nat. Meth. Vol.9. No.7. P.676.

Skogh C., Garm A., Nilsson D.E., Ekström P. 2006. Bilaterally symmetrical rhopalial nervous system of 
the box jellyfish Tripedalia cystophora // J. Morphol. Vol.267. No.12. P.1391-1405.

Van Lieshout J.S., Martin V.J. 1992. Development of planuloid buds of Cassiopea xamachana (Cnidaria: Scyphozoa) // Trans. Am. Microsc. Soc. Vol.111. No.2. P.89-110.

Walker R.J., Papaioannou S., Holden-Dye L. 2009. A review of FMRFamide-and RFamide-like peptides in metazoan // Inv. Neurosci. Vol.9. No.3-4. P.111-153.
Watanabe H., Fujisawa T., Holstein T. W. 2009. Cnidarians and the evolutionary origin of the nervous system // Dev. Growth Differ. Vol.51. No.3. P.167-183.

Wurm C.A., Neumann D., Schmidt R., Egner A., Jakobs S. 2010. Sample preparation for STED microscopy // Live Cell Imaging. Humana Press.

Responsible editor E.N. Temereva 